\title{
Development of Learning Media Applications for Information and Communication Technology Subjects as a Learning Aid for Junior High Schools
}

\author{
Budi Murtiyasa ${ }^{1}$, Riska Rahmawati ${ }^{2, *}$ \\ ${ }^{1}$ Informatics Engineering and Mathematics Education, Universitas Muhammadiyah Surakarta, Surakarta, Indonesia \\ ${ }^{2}$ Informatics Engineering Education, Universitas Muhammadiyah Surakarta, Surakarta, Indonesia
}

Received November 19, 2020; Revised January 5, 2021; Accepted February 17, 2021

\section{Cite This Paper in the following Citation Styles}

(a): [1] Budi Murtiyasa, Riska Rahmawati, "Development of Learning Media Applications for Information and Communication Technology Subjects as a Learning Aid for Junior High Schools," Universal Journal of Educational Research, Vol. 9, No. 3, pp. 564 - 578, 2021. DOI: 10.13189/ujer.2021.090316.

(b): Budi Murtiyasa, Riska Rahmawati (2021). Development of Learning Media Applications for Information and Communication Technology Subjects as a Learning Aid for Junior High Schools. Universal Journal of Educational Research, 9(3), 564 - 578. DOI: 10.13189/ujer.2021.090316.

Copyright $(2021$ by authors, all rights reserved. Authors agree that this article remains permanently open access under the terms of the Creative Commons Attribution License 4.0 International License

Abstract Information and Communication Technology (ICT) plays an important role, especially in the field of education. The Indonesian government has decided that ICT is one of the compulsory subjects for Junior High School children. In several schools in Indonesia, the teachers still use conventional methods in learning. It is necessary to innovate learning media applications for student learning aids in schools. This type of research is Research and Development (R\&D) using the ADDIE method (Analyze, Design, Development, Implementation, Evaluate). The populations in this study were students of $9^{\text {th }}$ grade junior high school in Cepu, Central Java, Indonesia. A total of 62 students from two different classes were included in this study, which were defined as the experimental group and the control group. Data collection techniques used test and questionnaire methods. The data analysis technique is a combination of qualitative and quantitative methods. The results of this study are as follows: (1) The assessment of the media expert got a value of 0.84 which could be declared valid, (2) The evaluation of the material expert got a value of 0.86 which could be declared valid, (3) The student's assessment got a value of 64.11 which can be categorized as marginal, (4) The students learning outcomes of the experimental class increased $17 \%$ than control class. From the results of the analysis and testing of research data, it can be concluded that the learning media can improve students learning outcomes from the previous method.

Keywords ICT, Architecture Computer, ADDIE, Media of Learning

\section{Introduction}

ICT experienced significant growth from 1990 to the present in countries with higher education institutions [1]. ICT is a technology in the field of information and communication based on electronics which is used for retrieval, collection, processing, storage, dissemination and presentation of data, information and content [2]. Now ICT is popularly used in educational field for making teaching learning process successful and interesting for students and teachers both [3], [4]. ICT in education has a very important role to expand access, reduce costs and improve the quality of education [5].

The development of ICT has had an influence on the field of education in the learning process. The use of ICT in the learning process is no longer a strange thing in the globalization era. The existence of the internet allows us to learn anytime and anywhere with a very broad scope, for example, with the facilities of email, chat, e-books, e-libraries and so on, we can share information without 
having to come face to face with the information source. Because all the information can be easily accessed in the internet [6].

At this time, ICT plays an important role, especially in the field of education. So the Indonesian government decided that ICT became one of the compulsory subjects for Junior High School children. Through ICT subjects, junior high school students begin to learn with world technology that is growing rapidly. It is also expected that students can be more creative and supported by many existing innovations. One of the applications of ICT in education includes using multimedia facilities and internet media in learning process. Using multimedia facilities in learning process is realized by learning modules that are more interactive and attract the interest of learners, for example, the existence of explanations through voice / audio media and the addition of features can increase more active participation from students. Meanwhile, using internet media in learning process is expected to make it easier to get the information needed, therefore students are expected to be actively independent at seeking information required for the knowledge.

Measurement of ICT in education needs to be carried out because of the increasing demand for ICT data in education as basic information of educational statistic that supports ICT policies in education. ICT policies in education are used to provide ICT services in the form of data, information, content, applications, infrastructure, and human resources [2]. The indicators used to measure the progress of ICT in the education sector have been developed by the UNESCO Institute for Statistics and are described in the Guide to Measuring Information and Communication Technologies in Education. This indicator has been adopted and used in several studies, including the analysis of factors affecting the combination index of ICT at the primary and secondary school level using the Analytic Hierarchy Process (AHP) method [7] and research on comparative statistical comparison analysis of school aggregate data in each country which describes conditions of ICT integration and e-readiness in Asia [5].

ICT as a tool is proven to be able to increase student concentration by making learning activities more enjoyable so that it can improve student learning outcomes and behavior [8]. Teachers use ICT skills to prepare lesson plans for each material, look for learning resources, make presentations / deliver material using digital media, also make teaching and learning process more enjoyable for students [9]. Learning in the 2013 curriculum uses a scientific approach [10]. Scientific learning is a collaborative learning process that focuses on the main learning experience, namely: (1) students observe every lesson delivered by the teacher both in explaining lessons, presenting teaching materials, and assigning assignments to students, (2) students are able to ask questions according to the learning substance implemented because asking questions is the first step in developing students' mindsets in responding to what they know and what they don't know, (3) students are able to collect information well, (4) students are able to associate each lesson they receive and what they understand, (5) students are also able to communicate all things about science to everyone in any environment [11].

The use of ICT in education often faces several obstacles, including: 1) lack of legal instruments in the field of ICT; 2) lack of ICT infrastructure procurement in several regions; 3) use of second-hand technology equipment because it is much cheaper; 4) high costs of procuring and using ICT facilities. To solve the problems mentioned above, a solution is needed as a condition for the successful application of ICT in the learning process, namely: 1) teachers and students must have access to digital technology and the internet in schools; 2) interactive learning materials using a laptop / computer; 3 ) teachers must have the ability and skills in using digital tools; 4) there must be sufficient budget to provide, develop, and maintain facilities and infrastructure and there must be support from all parties, including principals, teachers, and students in implementing ICT learning.

The use of ICT for learning in schools can improve learning outcomes by increasing the level of student confidence and student concentration. As for those who need to be considered in using of ICT for learning in schools, among others, the regulation of the number of hours of study with ICT, the ICT media used and the ability of teachers to use ICT [9]. The main indicators of ICT cover five sectors, namely: 1) ICT infrastructure and access; 2) Access to and use of ICT by households and individuals; 3) Access to and use of ICT in business; 4) ICT and trade sector; 5) Access to and use of ICT in the education sector. Indicators of access and use of ICT in the education sector were developed by the UNESCO Institute for Statistics (UIS) [5].

Based on the above, the researcher is interested in conducting a research entitled "Development of Learning Media Applications for Information and Communication Technology (ICT) as a Learning Aid for Junior High Schools". The learning media used is a computer system application. The presence of multimedia-based learning media can improve the quality of education [12], [13]. This study aims to increase student learning facilities that can help facilitate the teaching and learning process in schools and also test the effectiveness of learning using instructional media applications.

\section{Methods}

This study is a Research and Development (R\&D) using the ADDIE model approach (Analyze, Design, Development, Implementation, Evaluation). Researchers conducted the analyze stage at school by interviewing 
teachers and students to get conclusions about the problems that existed at school. At the design stage, the researcher analyzed the subject matter, lesson planning and assessment instruments that would be used in the research. The development stage tests the application to material experts and media experts. In the implementation stage, students learn to use learning media applications. Finally, the evaluate stage is carried out to conclude what things still need to be improved. Products should not be in tangible form or often called tools but also, might be in application form or software that can be installed on a computer [14].

The respondents of this study were $9^{\text {th }}$ grade from a junior high school in Cepu, Central Java, Indonesia. In this school, international standard is considered sufficient to use learning support applications with adequate facilities. Teachers in school environment really appreciate the new methods of learning so students are more enthusiastic. Total of respondents are 62 students who are divided into two groups, 31 students in the control class and 31 students in the experimental class. They are given lessons using two different methods, namely the lecture method and using learning applications. These 62 students are in an ordinary class, where their ability standards are the same, so the results of filling out the questionnaire will be neutral.

The development of this learning media application uses the Construct 2 software, while the design uses Adobe Photoshop. In developing this application, the computer used is the MacBook Air middle 2013 with a $1.3 \mathrm{GHz}$ Core i5 processor. This application can be run on a Windows PC with specification a 64-bit processor, with a speed of up to $4.7 \mathrm{Ghz}$ and has a cache of 12MB. Retrieval of data used tests and questionnaires, taking scores used the pretest and posttest which are divided into two class groups, namely the control class and the experimental class. The control class uses conventional learning methods, while the experimental class uses learning media applications in order to see the differences between the two. The questionnaire is used to see the students' opinions about the use of instructional media applications and also for evaluation by researchers.

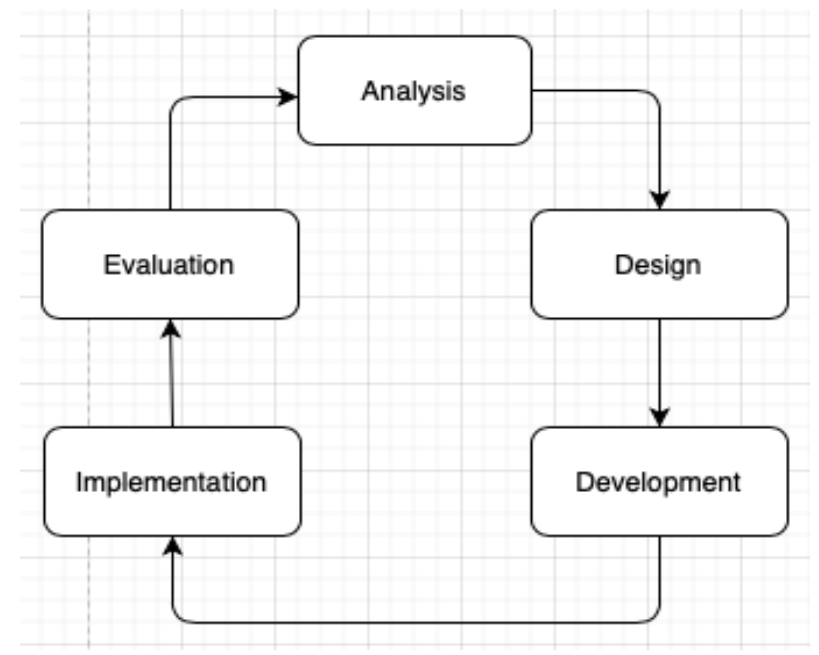

Figure 1. ADDIE Model

Figure 1 shows the stages of the ADDIE model approach. The first stage is analysis, then the design stage begins by identifying the material to determine the assessment instrument. The development stage starts by developing the product to test the product to material experts and media experts. The implementation phase begins with students learning to use learning media applications. Finally, the evaluation stage is carried out to conclude what's next to be improved.

Figure 2 is an activity diagram of the flow of learning media applications. In this application there is a menu of Materials, Videos, Quiz, Games, Settings, and Info. 


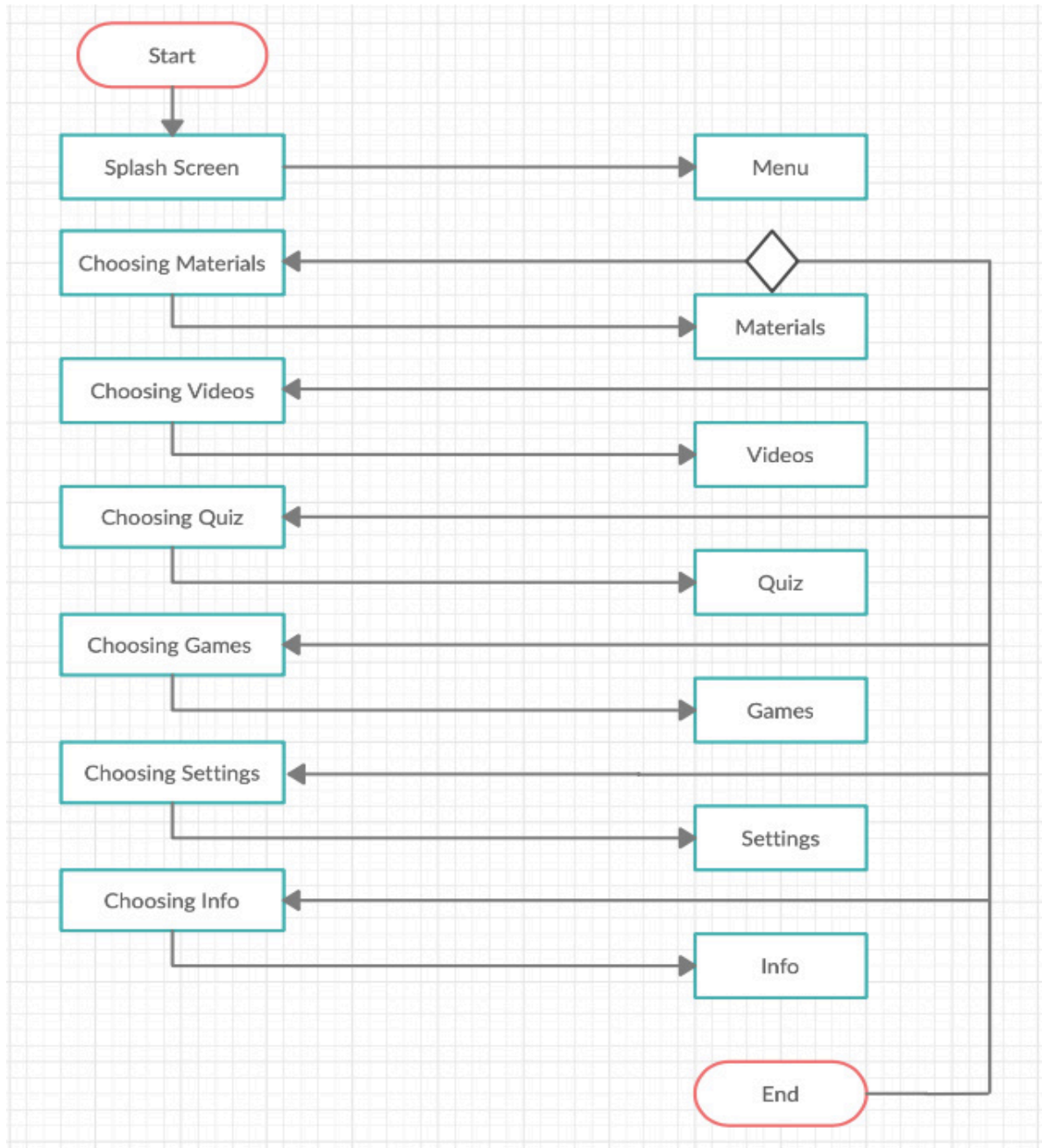

Figure 2. Activity Diagram

Various research methods can be seen from the foundation of philosophy, data and analysis which are grouped into three, namely qualitative, quantitative, and combination [15]. Analysis of the data in this study uses qualitative and quantitative methods. Qualitative data are obtained from the results of testing by media experts and material experts which will be processed into the final result using the Aiken $\mathrm{V}$ formula. The formula used in calculating $\mathrm{V}$ is as follows:

$$
\mathrm{V}=\frac{\Sigma^{S}}{[n(c-1)]}
$$

$\mathrm{s}=\mathrm{r}-\mathrm{lo}$

lo $=$ the lowest validation score

$\mathrm{r}=$ the number given by the assessor

$\mathrm{c}=$ the highest validation score

$\mathrm{n}=$ the number of assessors

Quantitative data are obtained from student/user assessments which will be processed into the final result using the SUS (System Usability Scale) from John Brooke [16]. The following is the calculation formula for SUS:

$$
\bar{x}=\frac{\sum x}{N}
$$

$\bar{x}=$ Average Score

$$
\begin{aligned}
& \sum x=\text { Total Score } \\
& \mathrm{N}=\text { Number of respondents }
\end{aligned}
$$

\section{Results and Discussion}

The learning media aimed at $9^{\text {th }}$ grade students of odd semester in ICT subjects. In this learning media, it discusses material about basic networks and complete computer architecture along with explanatory videos and practice questions. The making of this learning media uses the Construct application with the support of other applications for making image designs, namely PhotoShop. This learning media application has been tested by media experts and material experts before being tested on students to determine its feasibility.

The data from the research results were obtained from filling out questionnaires by students, and validation filled out by media experts and material experts. The results of these data will be processed and conclusions drawn at the end of this study. Students are also given a pretest and posttest to measure the effect of this learning media on classroom learning. 


\section{The Define and Design Stages}

The following are the results of developing instructional media application products.

Figure 3 is a splash screen display of the application before entering the main menu page. To be able to enter the main menu page, press the screen anywhere, it will pass through the splash screen and display the main menu page.

Figure 4 is main menu display. There are several menus including settings menu, info menu game menu, video menu, material menu and question menu.

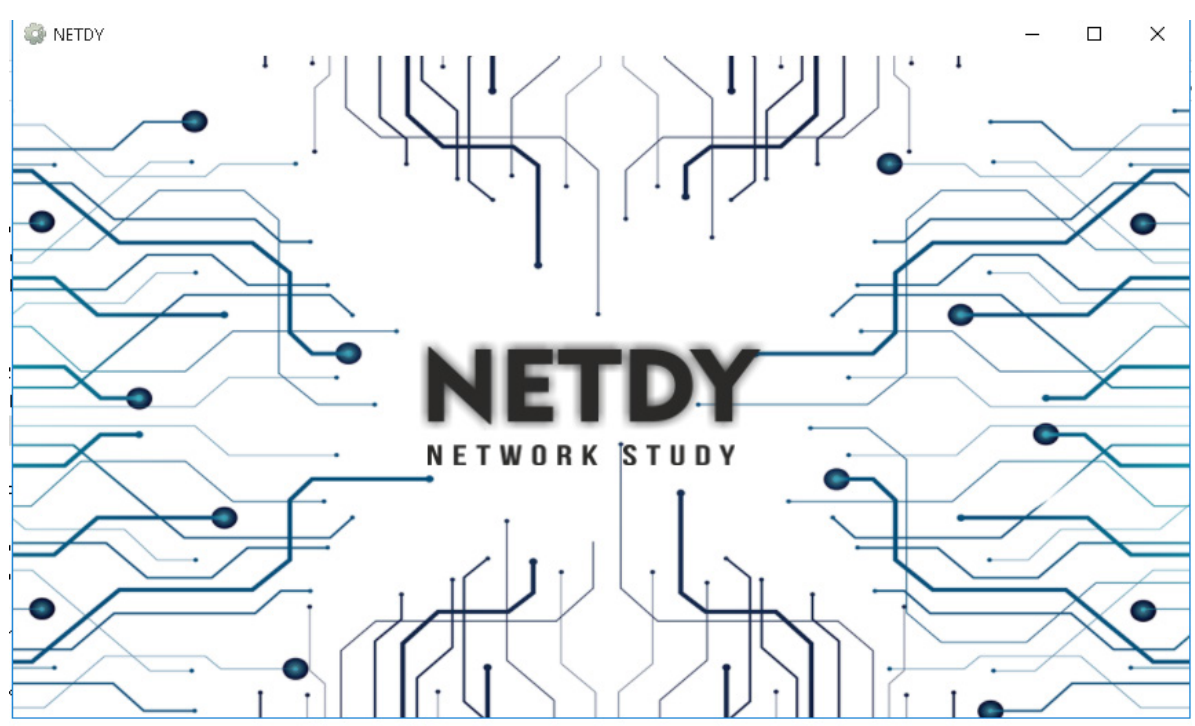

Figure 3. Splash Screen

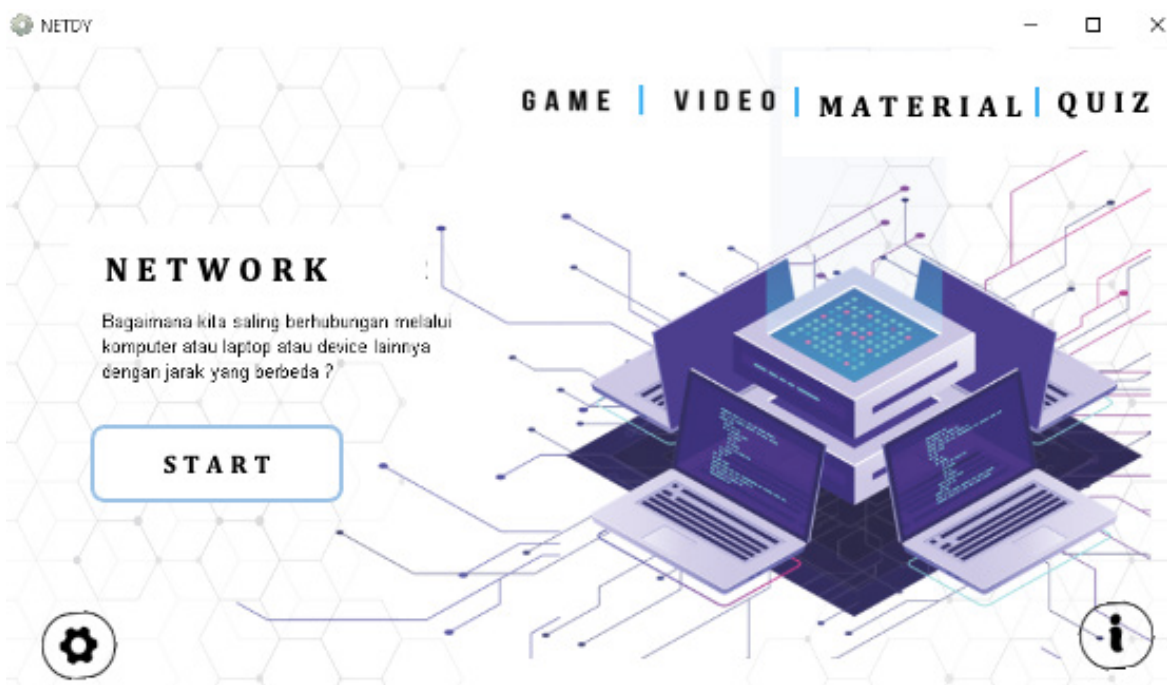

Figure 4. Main Menu 
Figure 5 is a display of the settings menu, which contains settings to turn on and turn off the sound or music in the application.
Figure 6 is a display of the info menu which contains the researchers' brief personal data, including name, initial number, university, and social media.

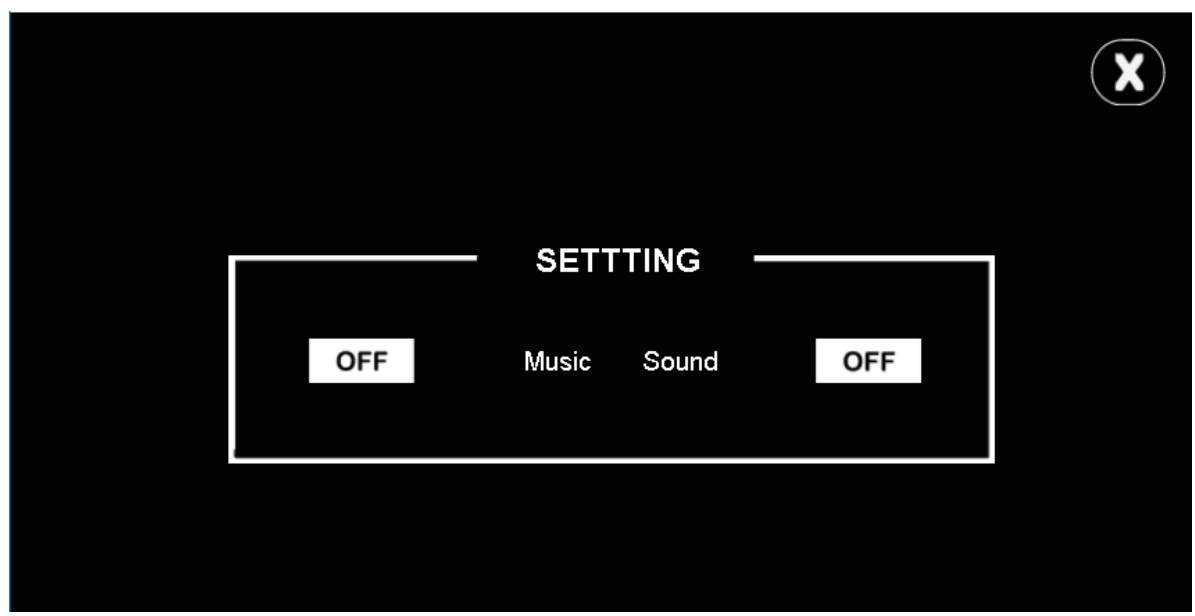

Figure 5. Setting Menu

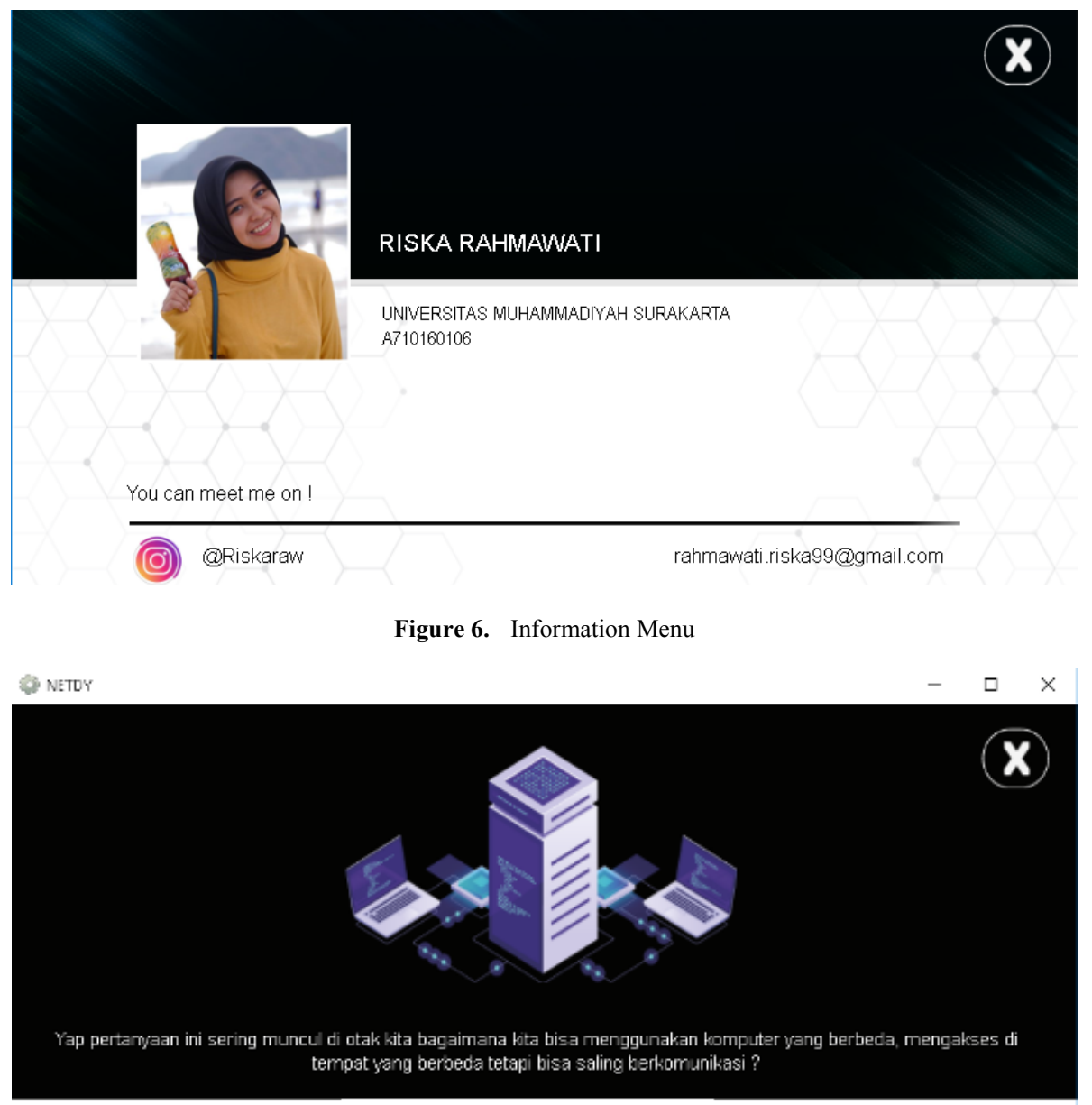

The answer is network

Network is a system that connects the devices to be used together in arrow range. Computer network consists of a number of computers and other network devices, then it called nodes, where they are all connected to ane another with or without cables.

Figure 7. Network Material 
Figure 7 is a display of network material that is on the main menu page. The $(\mathrm{X})$ button is used to close the material and will return to the main page menu.

Figure 8 is a menu game in which there are two games, namely the message introduction and the ping command. This game only aims for an interlude in learning, but there is still an educational element, so it doesn't disturb students in learning.

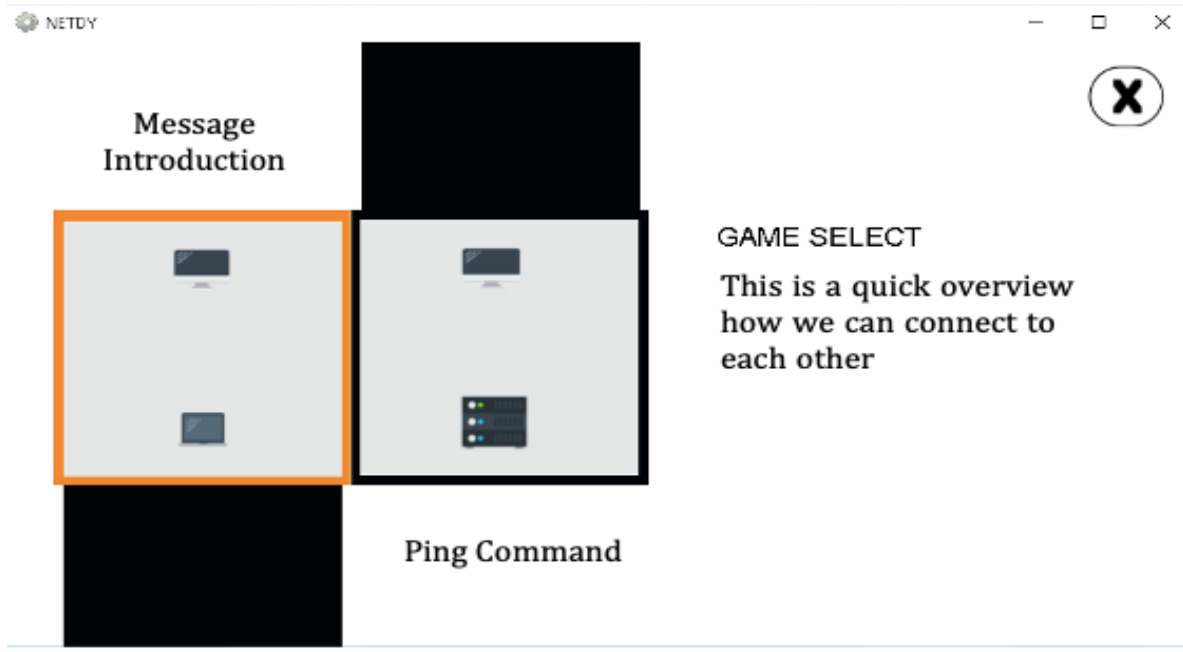

Figure 8. Menu Game

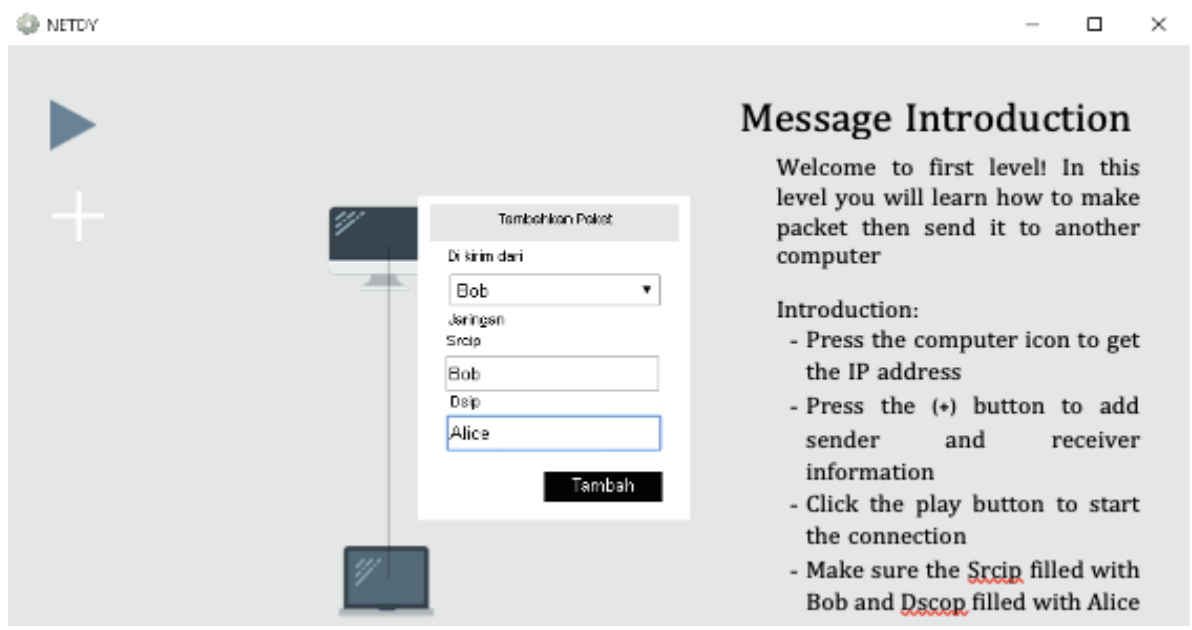

Figure 9. Game Display

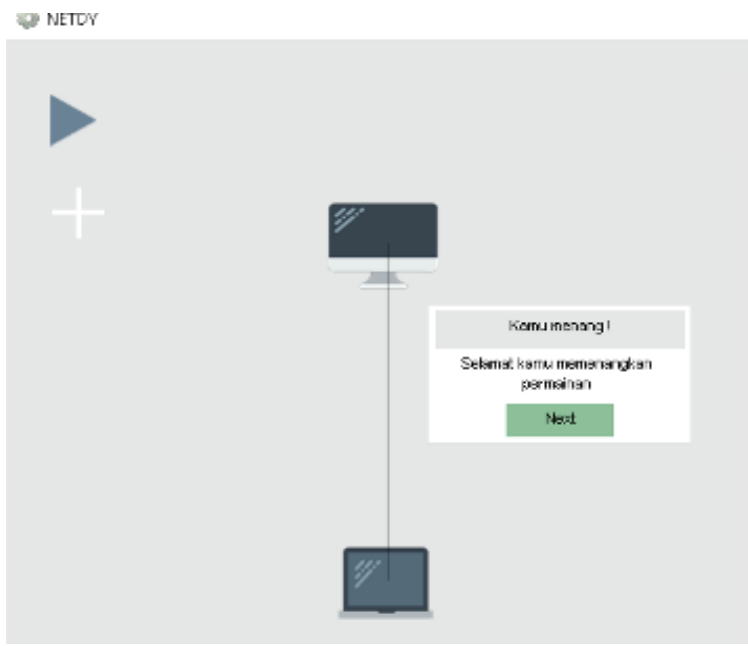

\section{Message Introduction}

Welcome to first level! In this level you will learn how to make packet then send it to another computer

Introduction:

- Press the computer icon to get the IP address

- Press the (*) button to add sender and receiver information

- Click the play button to start the connection

- Make sure the Srcip filled with Bob and Dscop filled with Alice

Figure 10. Game Display 
Figure 9 and 10 are views one of two games which names game introductory. Before playing, students are given an explanation right next to the game which aims to make students understand the concept of the game and also explain how to play it.

Figure 11 is a video menu display. It contains an animated video that explains the material in detail and illustrates it through an animated video. The $(>)$ button is the button that functions to move to the next video, while the $(<)$ button is the button that functions to move the previous video.

Figure 12 is a display of the hardware network material. There are explanations and sample pictures in it so that students can know the functions and forms at once. The $(>)$ button is a button that functions to move to the next material.
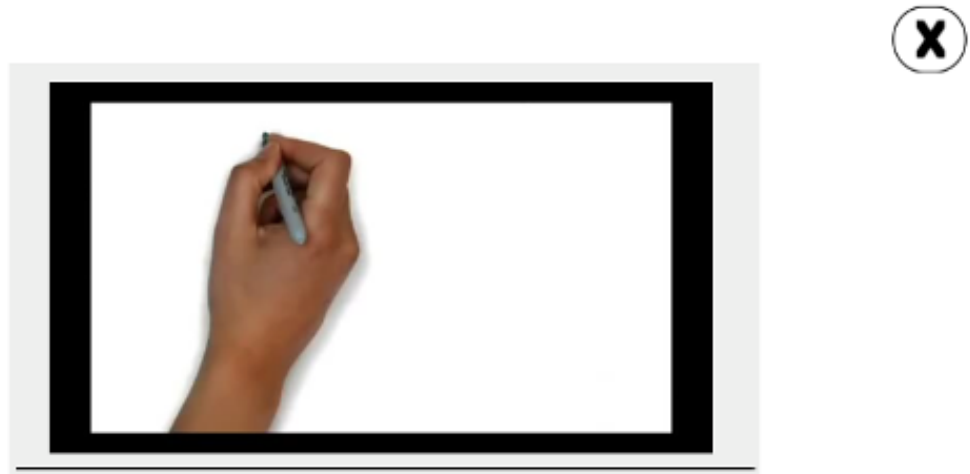

\section{Designing Computer Network}

Figure 11. Video Menu
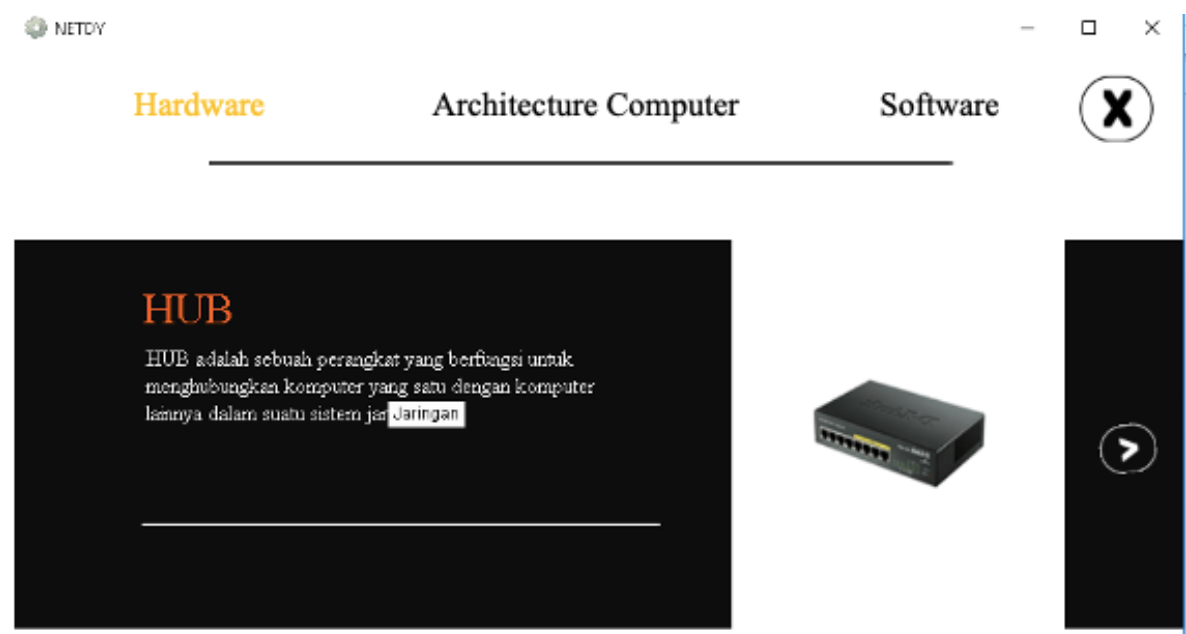

Figure 12. Hardware Network Material 


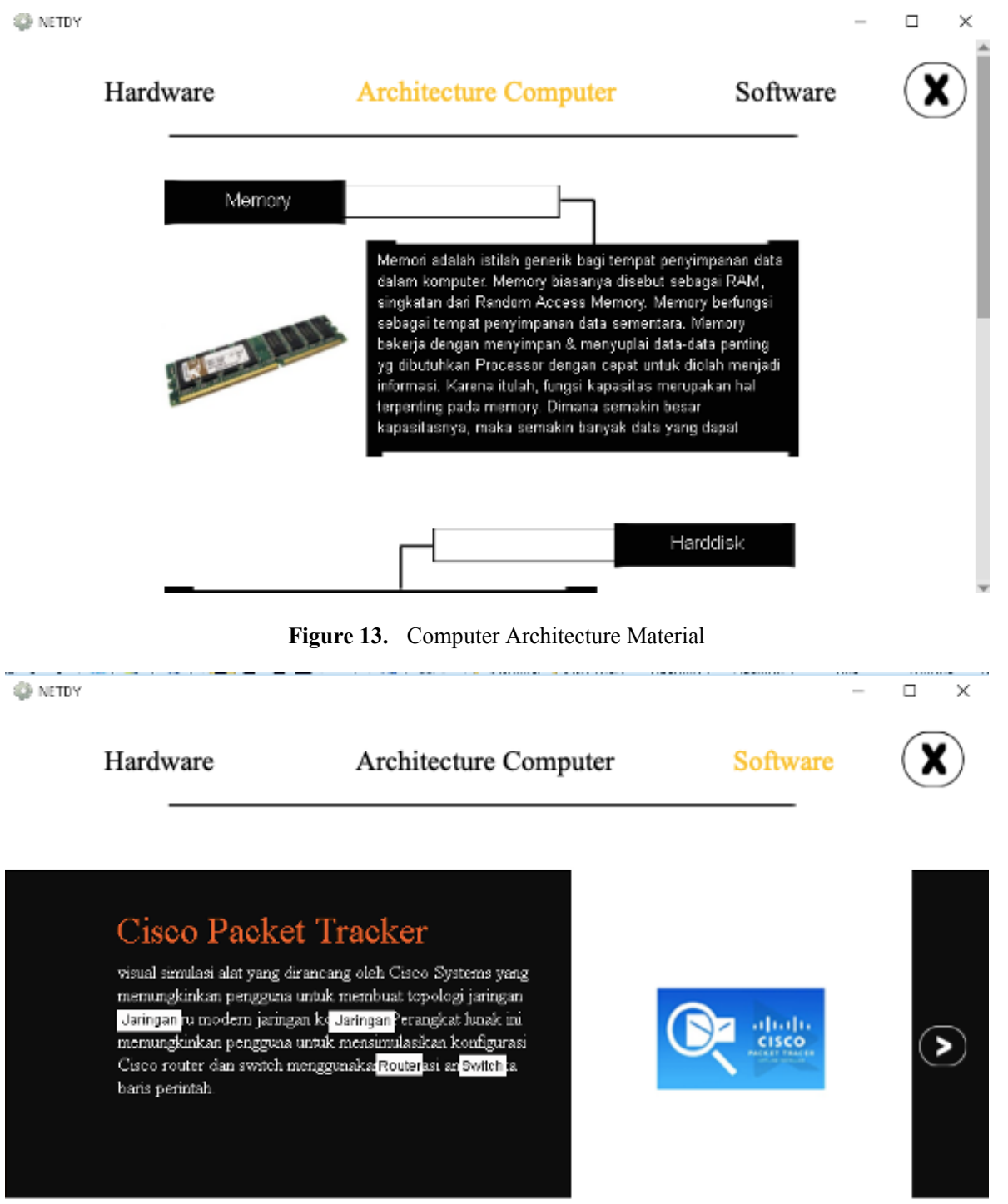

Figure 14. Software Network Material

Figure 13 is a menu display of computer architecture material. Still the same as the previous material, it contains an explanation accompanied by a picture. In this material menu students can use the scroll down button to be able to see the next material.
Figure 14 is a display of the software network material. In this area there is also an explanation and sample images. The function of $(>)$ button is to move to the next material. And the $(\mathrm{X})$ button is to return to the main menu. 
1. What is the function of the "PING" command in network?

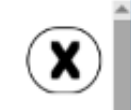
a. To test network connectivity
b. To know the network port number
c. To delete command history in the network
d. To change MAC address to be IP address

2. The characteristics of computer networks are as follows, except..
a. Share hardware
b. Share software
c. Share user
d. Share communications

Figure 15. Quiz Menu

\% NERV

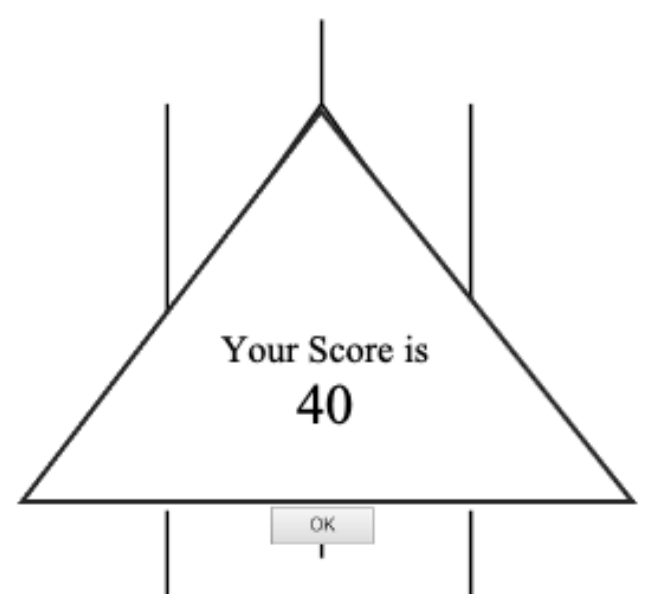

Figure 16. Score Display

Figure 15 is a display of the quiz menu which contains 10 multiple choice practice questions that students can do after studying all the material on the material menu.

Figure 16 displays the score menu display where students can see the final score after working on the questions. Every correct answer in each question will get 10 points, and for wrong or empty answer will not get points or 0 point. In total there are 100 points if students can answer all the questions correctly. 


\section{Media Expert}

Expert testing was carried out by three respondents. The following are the results of the media expert's assessment:

Table 1. Media Expert Assessment

\begin{tabular}{|c|c|c|c|c|c|c|c|c|c|c|c|c|c|c|c|c|c|c|c|c|c|}
\hline $\mathrm{R}$ & Q1 & Q2 & Q3 & Q4 & Q5 & Q6 & Q7 & Q8 & Q9 & Q10 & Q11 & Q12 & Q13 & Q14 & Q15 & Q16 & Q17 & Q18 & Q19 & Q20 & Total \\
\hline $\mathrm{V}$ & 0,89 & 0,89 & 0,78 & 0,67 & 0,78 & 0,78 & 1 & 1 & 0,78 & 0,89 & 1 & 0,89 & 0,78 & 0,89 & 0,89 & 0,89 & 0,78 & 0,78 & 0,78 & 0,69 & 16,81 \\
\hline
\end{tabular}

Note: $\mathrm{R}=$ Respondent

$\mathrm{V}=$ Validity Value

$$
\text { Average Values }=\frac{16,81}{20}=0,84
$$

The validity testing of three media experts explained the results of the paritem coefficient and the mean of the respondents. According to the Aiken $\mathrm{V}$ table limit, 20 items are defined a lower limit of 0.64 to an upper limit of 0.93 or a value of $\mathrm{V}$ reaching 0.83 . The data above show an average value of 0.84 . Then it can be declared valid according to the Aiken limit table.

\section{Material Expert}

The material expert testing was carried out by three respondents. The following are the results of the material expert's test:

Table 2. Material Expert Assessment

\begin{tabular}{|c|c|c|c|c|c|c|c|c|c|c|c|c|c|c|c|c|}
\hline $\mathrm{R}$ & Q1 & Q2 & Q3 & Q4 & Q5 & Q6 & Q7 & Q8 & Q9 & Q10 & Q11 & Q12 & Q13 & Q14 & Q15 & Total \\
\hline V & 0,89 & 0,67 & 0,89 & 0,78 & 0,78 & 0,89 & 0,89 & 1 & 1 & 0,89 & 0,89 & 0,89 & 0,89 & 0,89 & 0,67 & 12,91 \\
\hline
\end{tabular}

$\mathrm{V}=$ Validity Value 


$$
\text { Averages Values }=\frac{12,91}{15}=0,86
$$

The validity test of three material experts explained the results of the paritem coefficient and the mean of the respondents. According to the Aiken $\mathrm{V}$ table limit, 15 items are specified a lower limit of 0.64 to an upper limit of 0.93 or a value of $\mathrm{V}$ reaching 0.83 . The data above show an average value of 0.86 . Then it can be declared valid according to the Aiken limit table.

\section{User Questionnaire}

The assessment aspect for students uses SUS method (System Usability Scale) from John Brooke [16] which is commonly used as a research instrument. Filling in the questionnaire was only carried out by experimental class students who used the learning media application. The contents of the assessment questionnaire are as follows:
Table 3. User Questionnaire

\begin{tabular}{|c|c|c|c|c|c|c|}
\hline \multirow{2}{*}{ No. } & Questionnaire Aspects & \multicolumn{5}{|c|}{ Score } \\
\hline & & $\mathbf{1}$ & $\mathbf{2}$ & $\mathbf{3}$ & $\mathbf{4}$ & $\mathbf{5}$ \\
\hline 1. & I will use this learning media again. & & & & & \\
\hline 2. & I think this learning media is boring. & & & & & \\
\hline 3. & I find this learning media easy to use. & & & & & \\
\hline 4. & $\begin{array}{c}\text { I need help from others to use this } \\
\text { media. }\end{array}$ & & & & & \\
\hline 5. & $\begin{array}{c}\text { I consider the features provided are } \\
\text { easy to use. }\end{array}$ & & & & & \\
\hline 6. & I find this media less attractive. & & & & & \\
\hline 7. & $\begin{array}{c}\text { I better understand the material with } \\
\text { this medium. }\end{array}$ & & & & & \\
\hline 8. & $\begin{array}{c}\text { I find this medium difficult to } \\
\text { understand }\end{array}$ & & & & & \\
\hline 9. & $\begin{array}{c}\text { I feel that this medium can only be } \\
\text { used at school. }\end{array}$ & & & & & \\
\hline 10. & I find this medium complicated. & & & & & \\
\hline
\end{tabular}

SUS score range criteria:

$1=$ Strongly Disagree

$2=$ Disagree

$3=$ Enough

$4=$ Agree

$5=$ Strongly Agree

Table 4. User Assessment

\begin{tabular}{|c|c|c|c|c|c|c|c|c|c|c|c|}
\hline Respondents & Q1 & Q2 & Q3 & Q4 & Q5 & Q6 & Q7 & Q8 & Q9 & Q10 & SUS Score \\
\hline R1 & 3 & 4 & 4 & 2 & 4 & 4 & 2 & 4 & 1 & 3 & 77,5 \\
\hline $\mathrm{R} 2$ & 3 & 1 & 1 & 1 & 1 & 0 & 1 & 3 & 1 & 1 & 32,5 \\
\hline R3 & 2 & 3 & 2 & 2 & 3 & 3 & 2 & 3 & 0 & 2 & 55 \\
\hline $\mathrm{R} 4$ & 3 & 2 & 4 & 1 & 3 & 2 & 3 & 2 & 3 & 2 & 62,5 \\
\hline $\mathrm{R} 5$ & 3 & 4 & 3 & 1 & 2 & 4 & 3 & 3 & 1 & 3 & 67,5 \\
\hline R6 & 3 & 4 & 3 & 2 & 3 & 3 & 0 & 3 & 1 & 3 & 62,5 \\
\hline R7 & 3 & 4 & 3 & 2 & 3 & 3 & 4 & 3 & 1 & 3 & 72,5 \\
\hline $\mathrm{R} 8$ & 2 & 3 & 4 & 3 & 3 & 3 & 3 & 3 & 1 & 3 & 70 \\
\hline $\mathrm{R} 9$ & 3 & 3 & 3 & 3 & 4 & 2 & 3 & 3 & 1 & 3 & 70 \\
\hline R10 & 3 & 3 & 3 & 1 & 3 & 3 & 3 & 3 & 1 & 3 & 65 \\
\hline R11 & 3 & 3 & 4 & 0 & 3 & 3 & 3 & 3 & 0 & 4 & 65 \\
\hline $\mathrm{R} 12$ & 2 & 3 & 3 & 3 & 3 & 2 & 2 & 2 & 1 & 3 & 60 \\
\hline R13 & 2 & 3 & 3 & 2 & 3 & 3 & 1 & 3 & 2 & 3 & 62,5 \\
\hline R14 & 2 & 1 & 2 & 0 & 1 & 2 & 1 & 0 & 2 & 0 & 27,5 \\
\hline R15 & 3 & 3 & 4 & 1 & 3 & 3 & 2 & 3 & 1 & 3 & 65 \\
\hline R16 & 3 & 3 & 2 & 0 & 2 & 3 & 2 & 2 & 0 & 2 & 47,5 \\
\hline R17 & 2 & 3 & 3 & 1 & 3 & 2 & 2 & 3 & 2 & 3 & 60 \\
\hline R18 & 2 & 4 & 4 & 2 & 3 & 3 & 2 & 3 & 3 & 3 & 72,5 \\
\hline R19 & 2 & 3 & 4 & 2 & 3 & 1 & 4 & 3 & 4 & 3 & 72,5 \\
\hline $\mathrm{R} 20$ & 3 & 3 & 3 & 2 & 2 & 3 & 2 & 4 & 1 & 3 & 65 \\
\hline $\mathrm{R} 21$ & 3 & 3 & 3 & 0 & 4 & 3 & 3 & 3 & 1 & 3 & 65 \\
\hline R22 & 4 & 1 & 2 & 1 & 2 & 3 & 3 & 3 & 1 & 2 & 55 \\
\hline R23 & 4 & 3 & 3 & 1 & 3 & 4 & 2 & 1 & 0 & 4 & 62,5 \\
\hline R24 & 3 & 4 & 3 & 3 & 3 & 4 & 4 & 4 & 3 & 4 & 87,5 \\
\hline $\mathrm{R} 25$ & 2 & 4 & 3 & 0 & 3 & 3 & 2 & 3 & 4 & 0 & 60 \\
\hline R26 & 3 & 3 & 3 & 2 & 4 & 2 & 4 & 3 & 2 & 3 & 72,5 \\
\hline R27 & 3 & 2 & 1 & 0 & 3 & 4 & 3 & 2 & 1 & 1 & 50 \\
\hline R28 & 3 & 3 & 3 & 1 & 4 & 4 & 3 & 3 & 1 & 4 & 72,5 \\
\hline R29 & 3 & 3 & 3 & 3 & 3 & 3 & 3 & 3 & 1 & 3 & 70 \\
\hline R30 & 4 & 4 & 4 & 4 & 4 & 4 & 4 & 4 & 3 & 4 & 97,5 \\
\hline R31 & 2 & 3 & 3 & 3 & 3 & 2 & 2 & 2 & 2 & 3 & 62,5 \\
\hline \multicolumn{11}{|c|}{ Total } & 1987,5 \\
\hline
\end{tabular}


The testing was carried out on the experiment class totaling 31 students from $9^{\text {th }}$ grade of Junior High School in Cepu. The above data are the results of the user test:

$$
\text { Average Values }=\frac{1987,5}{31}=64,11
$$

Table 4 is the result of a student questionnaire filled out by $319^{\text {th }}$ grade from Junior High School students in Cepu, with an average of 64.11 included in the category marginal calculated using the SUS (System Usability Scale) which consists of 10 questions that must be answered by students learning media users which experimental class.
To determine the SUS percentile ranking score as follows: a) A score of more than or equal to 80.3 is categorized as $\mathrm{A}$; b) A score greater than 74 or equal to 80.3 is categorized as B; c) A score of more than 68 and less than 74 is categorized as $C$; d) Scores greater than 51 and less than 68 are categorized as D; e) A score of less than 51 is categorized as E [17].

\section{Student Test Results}

Comparison of the scores of the control class and the experimental class students are conducted with the pretest and posttest. The results of the comparison of values are as follows:

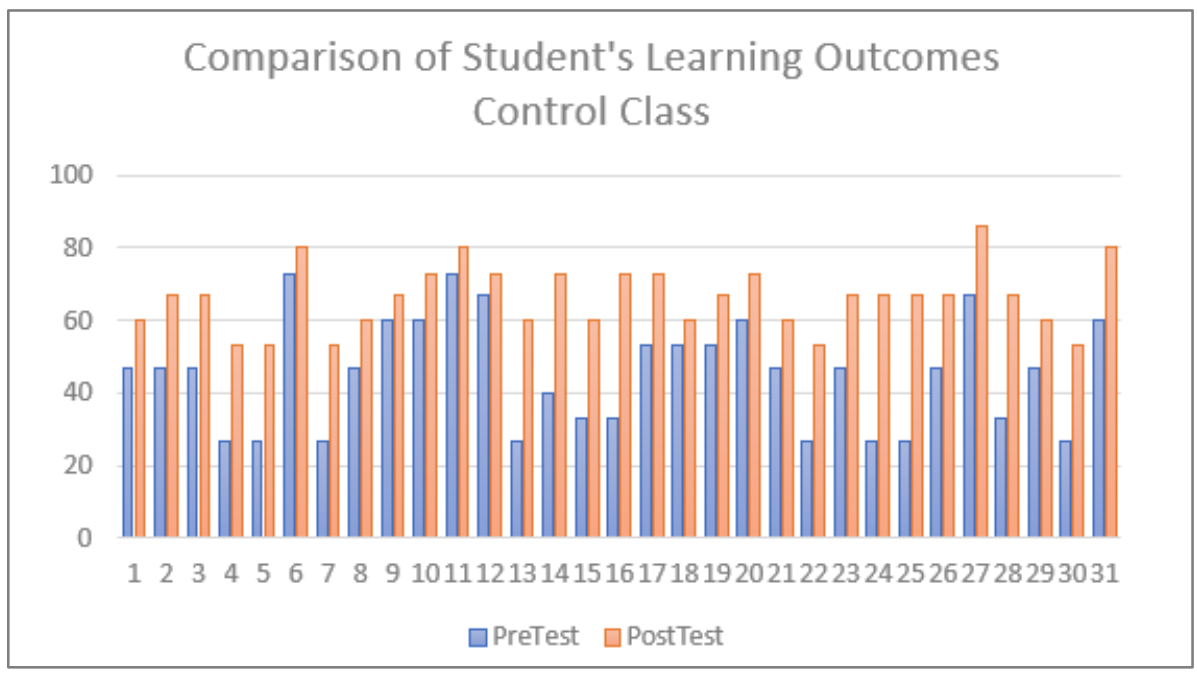

Figure 17. Student Learning Outcomes

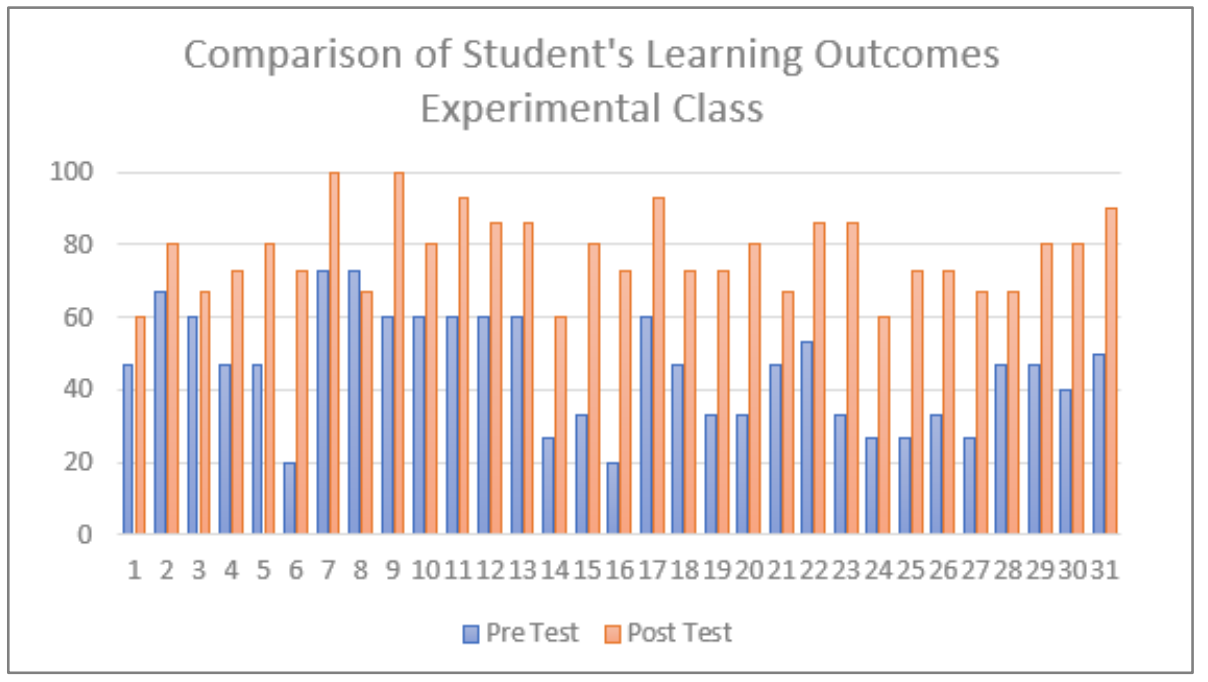

Figure 18. Student Learning Outcomes 
Figure 17 is the learning result of the control class students. Student scores tend to have less difference between the pretest and posttest because using the lecture method, they tend to be bored and don't pay attention to what the teacher explains during the learning process. The results of student learning also only increased $15 \%$ with an average pretest of 45.48 and an average of posttest of 61.19 .

Figure 18 is the result of the comparison of student learning outcomes from the experimental class before and after being treated. The pretest was tested on students before using the instructional media application. While the posttest is tested after students use the learning media application. The indicators tested are the same, in order to know the difference. As a result, the posttest score increased $32 \%$ compared to the pretest score. From the pretest results get an average of 45.74 while the average posttest score is 77.61 .

Compared to the scores of the control class, the results of the experimental class increased by $17 \%$, much better. This shows that the use of instructional media applications can improve student learning outcomes and can be used as a learning aid for students in school.

\section{Discussion}

The product developed by the researcher is the application of ICT learning media for junior high schools on basic Computer and Network Architecture material for $9^{\text {th }}$ grade. In this learning media there are features that can support student learning to be more interesting, including video material, games, material accompanied by pictures, practice questions, and arrangements for sound, such as research conducted by Murtiyasa et al. [18] with several features namely material, learning videos, quizzes, and discussion. Before developing the application, researchers analyzed the problems that existed in the school by interviewing teachers and students. After obtaining the required analysis, the researchers designed the design and carried out media development in order to add the latest innovations. This media development uses the Construct 2 software, such as research conducted by Agung et al. [19]. By using the Construct 2 software, we got a positive response from $8^{\text {th }}$ grade students in Junior High School. Students state that the application is interesting and can help them learn.

The application implementation stage in this study used two classes, namely the control class and the experimental class, as in the research conducted by Iswatun et al. [15], which uses a quasi-experimental research method with a pre test and post test control group design. Previously, the two classes were given the same treatment, that is given questions pretest to measure the level of prior knowledge possessed by students. Furthermore for the control class, the same material is given to the conventional method or lecture, while the experimental class given material using learning media applications, after students got the material, students are given post test questions to find out whether there is a difference in student learning outcomes after being treated. The control class got an average score of 61.19 , while the post test results from the experimental class got an average score of 77.61. The difference in value between the two is quite large, that is 16.42 .

This learning media application is used offline to make it easier for students and schools to use it because it does not need the internet which can reduce the cost of expenses. Unlike applications that have been made by Susilo and Rohman [6], the lack of competence of human resources in technology hinders the learning process online. This was also developed by Fuady [20] who also developed an online learning application.

This learning media application was developed to assist students in learning Computer Architecture and Basic Networks for grade IX students in the form of videos and material summaries supported by practice questions and games so that students don't get bored easily in the learning process, such as research conducted by Harliawan [21] who developed ICT learning media for $8^{\text {th }}$ grade with an average value of $28 \%$ increase.

Table 3 are the results of a questionnaire from $9^{\text {th }}$ grade Junior High School students in Cepu, totaling 31 students. From the table, the average score obtained is 64.11 which is included in the D category, because the average results obtained are included in the range 51 to 68 and this learning media application can be used to support the learning process of students in schools.

Based on the results of the analysis and testing of research data, it can be concluded that this learning media can improve student learning outcomes from the previous method. Due to the limitations of current researchers, for further research it is necessary to add some material and videos so that the material coverage is wider, as well as adding practice questions, and adding other games to make it more varied.

\section{Conclusion}

Based on the results and the previous discussion, it can be concluded that the media expert's assessment got a value of 0.81 which could be declared valid. The material expert's assessment got a value of 0.91 which could be declared valid. The student's assessment scores 64.11 which can be categorized as marginal. Student learning outcomes increased by $32 \%$ after using instructional media applications. From the results of analysis and testing of research data, it can be concluded that this learning media can improve student learning outcomes from the previous method. 


\section{REFERENCES}

[1] Prajana, A. "Pemanfaatan Aplikasi Whatsapp Untuk Media Pembelajaran Dalam Lingkungan Uin Ar-Raniry Banda Aceh.” Cyberspace: Jurnal Pendidikan Teknologi Informasi, 1(2) (2017): 122. https://doi.org/10.22373/cs.v1i 2.1980

[2] Kemdikbud. "Peraturan Menteri Pendidikan dan Kebudayaan No. 99 Tahun 2013 tentang Tata Kelola Teknologi Informasi dan Komunikasi di Lingkungan Kemdikbud". pp.1-4. 2013

[3] Bhattacharjee, Baishakhi, and Kamal Deb. "Role of ICT in 21 St Century's Teacher Education." International Journal of Education and Information Studies 6, no. 1 (2016): 1-6. http://www.ripublication.com.

[4] Khursheed Ahmad Khanday. "Role of ICT (Information \& Communication Technology) in 21st Century's Teacher Education." International Journal of Advanced Multidisciplinary Scientific Research 2, no. 1 (2019): 10-14. https://doi.org/10.31426/ijamsr.2019.2.1.1112.

[5] UNESCO Institute for Statistics. ICT in Education in ASIA : A comparative analysis of ICT integration and e - readiness in schools across Asia, Canada. 2014.

[6] Susilo1, Purnomo Hadi dan, and M. Ghofar Rohman. "Efektivitas Sistem Pembelajaran Online Sebagai Media Pembelajaran Berbasis Aplikasi Web Di Era Milenial." Seminar Nasional Sistem Informasi, no. September (2019). https://doi.org/https://jurnalfti.unmer.ac.id/index.php/senasi f/article/view/272.

[7] Aoki, H., Kim, J. and Lee, W. "Propagation \& level: Factors influencing in the ICT composite index at the school level", Computers \& Education 60 310-324. 2013.

[8] Hussain, A.J., Morgan, S. and Al-Jumeily, D. "How does ICT affect teachings and learning within school education." Proceedings - 4th International Conference on Developments in eSystems Engineering, DeSE 2011, pp.250-254. 2011.

[9] Umar, I.N and Yusoff, M.T.M, "A Study on Malaysian teacher's level of ICT skills and practices, and its impact on teaching and learning", Procedia - Social and Behavioral Sciences, 116 pp. 979-984. 2014.

[10] Mulyasa. Pengembangan dan Implementasi Kurikulum 2013, Remaja Rosdakarya, Yogyakarta, 2013.

[11] Nurdyansyah, and Eni Fariyatul Fahyuni. Inovasi Model.
Nizmania Learning Center, 2016.

[12] Junia Sandy, Rohmad, and Budi Murtiyasa. "Developing a Multimedia-Based Learning Media for Learning Matrix Transformation." Journal of Physics: Conference Series 1265, no. 1 (2019). https://doi.org/10.1088/1742-6596/1265 $/ 1 / 012020$.

[13] Ratheeswari, K. "Information Communication Technology in Education." Journal of Applied and Advanced Research 3, no. S1 (2018): 45. https://doi.org/10.21839/jaar.2018.v3is1. 169.

[14] Sutama. Metode Penelitian Pendidikan. Fairuz Media, Kartasura, 2016.

[15] Iswatun, Iswatun, Mosik Mosik, and Bambang Subali. "Penerapan Model Pembelajaran Inkuiri Terbimbing Untuk Meningkatkan KPS Dan Hasil Belajar Siswa SMP Kelas VIII.” Jurnal Inovasi Pendidikan IPA 3, no. 2 (2017): 150. https://doi.org/10.21831/jipi.v3i2.14871.

[16] J. Brooke, "SUS-A Quick and Dirty Usability Scale," Usability Eval. Ind., vol. 189, no. 194, pp. 4-7, 1996.

[17] Ependi, Usman, Febriyanti Panjaitan, and Hutrianto Hutrianto. "System Usability Scale Antarmuka Palembang Guide Sebagai Media Pendukung Asian Games XVIII." Journal of Information Systems Engineering and Business Intelligence 3, no. 2 (2017): 80. https://doi.org/10.20473/jis ebi.3.2.80-86.

[18] Budi Murtiyasa, Indah Miftakul Jannah, Sri Rejeki, "Designing Mathematics Learning Media Based on Mobile Learning for Ten Graders of Vocational High School," Universal Journal of Educational Research, Vol. 8, No. 11, pp. 5637- 5647, 2020. DOI: 10.13189/ujer.2020.081168.

[19] Agung Saputro, Titon, Kriswandani Kriswandani, and Novisita Ratu. "Pengembangan Media Pembelajaran Mengunakan Aplikasi Construct 2 Pada Materi Aljabar Kelas VII.” JTAM | Jurnal Teori Dan Aplikasi Matematika 2, no. 1 (2018): 1. https://doi.org/10.31764/jtam.v2i1.219.

[20] Fuady, Muhammad Jauharul. "PENGEMBANGAN APLIKASI EVALUASI PEMBELAJARAN ONLINE UNTUK PENDIDIKAN JARAK JAUH Muhammad Jauharul Fuady." Tekno 26, no. September (2016): 148-54

[21] Harliawan, Hendri. "Penggunaan Media Pembelajaran Berbasis TIK Untuk Meningkatkan Hasil Belajar IPS Kelas VIII J SMP Negeri 5 Singaraja.” Ekuitas: Jurnal Pendidikan Ekonomi 3, no. 1 (2015). https://doi.org/10.23887/ekuitas.v 3i1.12786. 